\title{
Utilization of Spent Hen in Food Industry- A Review
}

\author{
B. K. Sarkar ${ }^{1}$, S. Upadhyay ${ }^{2}$, P. Gogoi ${ }^{2}$, S. Choudhury ${ }^{3}$ and D. Deuri ${ }^{2}$ \\ ${ }^{1}$ Department of Livestock Products Technology, College of Veterinary Science and Animal \\ Husbandry, R. K. Nagar, West Tripura, Tripura- 799008, India \\ ${ }^{2}$ AICRP on Post Harvest Engineering and Technology, Department of Livestock Products \\ Technology, College of Veterinary Science, Assam Agricultural University, Khanapara, \\ Guwahati- 781 022, India \\ ${ }^{3}$ Department of Livestock Products Technology, College of Veterinary Science, Assam \\ Agricultural University, Khanapara, Guwahati- 781 022, India, India \\ *Corresponding author
}

\section{A B S T R A C T}

\section{Keywords}

Spent hen, Instant soup mix,

Communuted

product,

Restructured

products,

Convenient

products, Self stable

products

\section{Article Info}

Accepted:

14 June 2020

Available Online:

10 July 2020
The demand for convenience meat products is increasing globally due to rapid urbanization, changing lifestyles, increased per capita income, socioeconomic status and awareness about hygiene, nutritional, satiety and palatability characteristics. Meat being perishable food requires considerable input for chilling or freezing during storage and marketing which demand continuous energy supply. Spent hen meat, an excellent and cheaper source of animal protein can be effectively use for processing of convenient and self stable products for under developed and developing countries suffering serious protein energy malnutrition. Development of technologies for production of low-cost, safe and acceptable shelf stable spent hen meat products is need of the hour. The review is intended to provide an overview of the present status of the utilization of spent hen meat.

\section{Introduction}

Hens that have completed their laying cycle within one year are referred to and marketed as spent hen (Haque et al., 1991). Spent hens are considered as byproduct of egg industry (Mahapatra, 1992) which is rich in fat and cholesterol content, and poor in functional characteristics, juiciness and tenderness due to high collagen content (Abe et al., 1996) and high degrees of cross linkages (Wenham et al., 1973; Bailey, 1984) as compared to broiler meat. In spite of being similar nutritional quality of broiler meat (Chueachuaychoo et al., 2011), spent hens have minimal economic values (Baker et al., 1968; Mahapatra, 1984). 
The layer bird population of India was around 247 million in 2010 (Juse, 2012). With the rapid growth of poultry production, number of spent hens has also increasing. If the volume of biological matter, labor, and associated transportation costs are taken into account, the disposal of layer hens is one of the important economical and environmental problems of the poultry industry (Lyons, 2001). In addition, with the increase of broiler production, the sale of spent breeding hens at reasonable prices has become more difficult, affecting producers' profits (Kondaiah, 1993).

The moisture, protein, fat and total ash content of spent hen meat is 67.46, 24.36, 7.15 and $1.04 \%$, respectively (Lee et al., 2003). Spent hen meat is a good protein source (Lee et al., 2003), highly enriched with omega-3 fatty acids and lower in cholesterol content particularly breast muscle which has health promoting benefits. Chicken fat contains 67\% unsaturated fatty acids (MUFAs and PUFAs) compared to beef (42\%), pork (57\%) and lamb (46\%) (Hedrick et al., 1993). Spent hen meat is more prone to oxidation than broiler during processing and storage due to higher fat content consisting of high content of unsaturated fatty acids. Over last few years demand for poultry meat is growing because it is an excellent and cheaper source of animal protein food associated with low fat and low calorie food (Akiba et al., 2001). Effective utilization of layer birds after the end of their productive life is one of the urgent requirements of Indian poultry industry as 30 percent of the poultry slaughtered are spent hens (Juse, 2012).

Spent hens are usually used in feed production, concentrated stock preparations, or in domestic consumption of soups and stews (Ajuyah et al., 1992; VollerReasonover et al., 1997). To offer an alternative for spent hen, the hurdle technology described by Leistner and Gorris
(1995) has been introduced to process breast and thigh of spent hen meat. With breast and thigh meat samples of White Leghorn spent hen was preserved following hurdle measures using salting plus antioxidants, drying, and vacuum packaging. (Rocha Garcia et al., 2003).

\section{Convenience foods}

The demand for quality meat and meat products is ever increasing among quality conscious consumers due to growing awareness about hygiene, nutritional, satiety and palatability characteristics. Growing urbanization coupled with new pressures on the times of house wives, increasing number of women entering job, changing lifestyles, increased per capita income, consumer awareness and socio-economic status have also contributed to the enhanced consumption of processed and convenience meat products ready-to-eat, heat and serve convenience meat products (Kumar et al., 2001; Deogade et al., 2008). Convenience foods are classes of foods which impart convenience to the consumers as it require little or no major processing or cooking before consumption. Convenience foods just require mild heating/warming for ready-to-reconstitute or ready-to-eat products or rehydration in hot/cold water for dehydrated foods (Premavalli, 2000). A wide spectrum of ready-to-eat and instant convenience mixes which find an immense use and application not only in defense but also in civilian sector includes precooked dehydrated convenience foods and instant convenience foods (Sharma and Bawa, 2003).

\section{Shelf stable meat products}

Meat being a nutritious food it is also perishable which require considerable input for chilling or freezing during storage and marketing of meat and meat products. Meat is a favourable medium for the growth of 
microorganisms due to its high water activity, high levels of nutrients especially protein and neutral $\mathrm{pH}$. High perishability of meat and meat products is a serious problem in tropical countries like India. The scarcity of meat leads to the shortage of supplies in developing countries. This valuable food is spoiled readily unless held at chilling temperature and problem becomes more acute where cold storage facilities are absent in retail sector. One of the primary objectives of food processing is the conversion of perishable foodstuffs into shelf stable products. Preservation of meat either in fresh or in processed form requires considerable energy (Gadekar et al., 2010). Thus development of shelf stable foods is in high prerequisite to distribute it without refrigeration facility to various locations. Based upon various preservation techniques the meat products may be shelf stable like cured and canned products, snack type products, dry and intermediate meat products, meat powder etc.

\section{Comminuted products}

Improved deboning techniques and modern methods of meat processing could enhance the quality and value of spent hen meat leading to greater demands and better financial returns (Kondaiah and Panda, 1992). Different tenderizing agents were used to tenderize of spent hen meat (Mendiratta et al., 2004). Since spent layers are very cheap source of meat it can be used successfully in the formulation of many value added meat products (Kim and Ahn 1997). Poultry meat based products such as patties, sausages, nuggets, kabobs, samosa, etc. have substantial potential in western as well as in eastern countries (Patnaik, 1993). In India lot of potential exists for development of such processed products, though at present less than one percent of meat is being processed.

Development of comminuted meat products offers an important avenue for the profitable disposal of spent hens (Prabhakar Reddy and Srinivasarao, 1997). Utilization of meat from spent hen through further processed products has been attempted by several workers (Seideman et al., 1981). Addition of meat from different parts of spent chicken especially breast and leg muscle increased the quality of chicken nuggets (Mahapatra and Verma, 1998). Meat from spent bird is inferior compared to the broiler meat and can effectively be utilized by developing value added products (Rongsensusang et al., 2005). Spent hen meat can be utilize in sausage manufacture, since its hardness is not an obstacle for the production of most processed products, which use ground meat (Kondaiah and Panda, 1992). Utilization of semi heavy spent hen meat has potential for manufacture of mortadella-type sausages with vegetable oil (Souza et al., 2011).

Use of spent hen meat with substantial amounts of non-meat ingredients reduces undesirable characteristics of these meat in final products because of the inherent nature of the processes involved, or ingredient interactions during processing (Rhee et al., 1999). The sensory parameters and protein content of culled hen and broiler breeder male meat tikkas are influenced by binders, storage period and cooking (Sekhon and Bawa, 1991). Spent hen meat loaf extended with lentil flour had significantly more flavour and overall acceptability scores and lower tenderness scores than loaf extended with black gram flour and maida (Sachdev et al., 1996). Incorporation of caseinates and refined wheat flour in spent hen meat nuggets improves sensory scores (Rao et al., 1997). Incorporation of $1 \%$ sodium caseinates into the spent hen meat nuggets significantly improves the colour, flavour, juiciness, texture and overall acceptability scores than addition with $2 \%$ sodium caseinate or 1 and $2 \%$ calcium caseinates (Singh et al., 1997). General appearance, flavour, juiciness and texture of spent hen meat nuggets is affected 
with the level of incorporation of rice flour (Nag et al., 1998). Raw spent hen meat sausages was superior for appearance, flavour, juiciness, firmness and overall acceptability than sausages incorporated with skin, gizzard, heart and yolk (Prabhakara Reddy and Vijayalakshmi, 1998). Incorporation of skin (18-21\%) and giblets (12-14\%) in spent hen meat patties improve juiciness, tenderness and overall acceptability scores (Lingaiah and Prabhakara Reddy, 2001). Incorporation of any dried egg products except dried yolk significantly improved the appearance, colour and flavour scores of spent chicken meat patties (Kalaikannan et al., 2007). Incorporation of egg and potato in spent chicken meat nuggets leads to higher moisture content in products (Kondaiah et al., 1990).

\section{Restructured products}

Meat from spent birds is generally tough, dry and sinewy (Mediratta et al., 2004). Value enhancement of raw materials, portion control, uniform quality and consumer convenience are some of the advantages of restructured meat products. Products that undergone particle size reduction such as sectioning, chunking, slicing, flaking, blade tenderization, chopping followed by forming into steaks, roasts or patties are called restructured meats (Hedrick et al., 1994). Restructured meats can be bounded together through the formation of gel that is thermally set (Boles and Shand, 1999). Conventional restructured meat products using salt and phosphates depend on the thermal binding of myofibrillar proteins that are extracted from meat (Mandigo, 1986). In this perspective, it is necessary to evolve appropriate technology to convert the tough and less palatable spent hen meat in to convenient, attractive and more acceptable novel products. Restructured spent hen meat nuggets from spent hen meat emulsion is moderately to highly acceptable whereas from ground spent hen meat batter is moderately acceptable (Anna Anandh and Annal Villi, 2018). Restructured chicken steaks extended with texturized soy flour and milk co-precipitates improves color, texture, juiciness and overall acceptability (Bhoyar et al., 1997).

\section{Drying}

Drying is one of the oldest methods of food preservation and a very important aspect of food processing (Vadivambal and Jayas, 2007). It is the process of simultaneous heat and mass transfer operation in which water activity of a material is lowered by the removal of water (Kharaisheh et al., 1997) and thereby enabling microbial stability and consequent extension of shelf life of the product without compromising the desired attributes. Growing resistance to the use of chemicals for food preservation, and the demand to provide a comprehensive range of products, has led to a renewed interest in drying operations (Jayaraman et al., 1992). Dried meat products can be prepared by different methods, sun drying being the simplest and cheapest method of drying. However, it is a time consuming process and exposes meat to contamination from air that contains aerosolized microbes, insects, dust etc. The drawbacks can be reduced to an extent by drying meat in mechanical dryers or solar dryer.

Dried foods contain less than $25 \%$ moisture and a water activity less than 0.60 whereas intermediate moisture foods products contain between 15 and 50\% moisture and a water activity between 0.60 to 0.85 (Jay et al., 2005). The advantages of dried products are requirement of less storage space, ease of transport and non-requirement of cold chain facilities. Dried meat and meat products are rich in protein and serve as nutrient dense foods especially to malnourished people in under developed and developing countries. 


\section{Spent hen meat powder}

Spent hen meat powder is one of the best options to produce the shelf stable meat product. Powdered meat extracts are widely used by the food industry to provide flavour to snacks and instant sauces (Varnam and Sutherland, 1995). Although the gelling functionality of meat proteins is generally regarded to be greatly reduced after dehydration (Mackie, 1994), the cost saving benefits could still make meat powders attractive to the food industry as a substitute for raw meat ingredients. Chicken meat powder has been used in developing chicken enriched noodles to improve the nutritional quality of the products (Kumar, 2009).

Converting spent hen meat into meat powder increases its shelf life without substantial loss of quality, even at ambient temperature. Spent hen meat powder technology is useful in situations of low prices due to poor demand and disease scare situations like bird flu outbreak.

Value addition and effective utilization of the spent hen meat can be enhanced by processing the spent hen meat powder into ready-to-use convenience products. Besides, millions of people worldwide especially in under developed and developing countries suffer from serious protein energy malnutrition problem, due to acute shortage of animal protein in the diet.

To meet these demands, effective utilization of spent hen for the development of meat powder would not only provide scope for formulation of value added products but also supply protein-rich nutrients to the consumers.

\section{Chicken soup}

Soup is probably one of the oldest foods of human being, since it must have developed about the time when boiling was establish as very fast form of cookery. It is simple to prepare, relatively cheap, nutritious, easily digestible and highly cherished by young generation. Chicken soup is prepared by boiling the ingredients such as meat, vegetables and starch in hot water, until the flavour is extracted, forming a broth. For instance, it is regarded as the most ubiquitous medicinal soup in the world. Chicken soup has long been regarded as a remedy for symptomatic upper respiratory tract infections. Sipping warm soup can clear nasal passages, serving as a natural decongestant, which also relieves cold and flu symptoms. Chicken soup might have anti-inflammatory activity, namely, the inhibition of neutrophil migration (Barbara et al., 2000) and could hypothetically lead to temporary ease from symptoms of illness (Rennard et al., 2000). Normally soups are consumed before meals to stimulate the appetite and flow digestive juices in stomach. Chicken soup is often referred as "Jewish penicillin", "bohbymycetin" and "bobamycin" (Caroline and Schwartz, 1975; Saketkhoo et al., 1978).

Studies have been conducted on different types of chicken soup like chicken whey soup (Chidandandiah and Sanyal, 2001), chicken soup (Shukla et al., 2014) and instant soup mix (Gokulakrishnan, 2014). Spent hen meat being a good protein source, highly enriched with omega-3 fatty acids, lower cholesterol content and health promoting benefits (Chueachuaychoo et al., 2011) may successfully utilize in soup preparation.

\section{Instant soup mix}

Dry soup mixes are well recognized convenience food item in the world food markets. Instant soup mixes are preferred more as dry soup mixes by consumers because of their convenience in preparation, shelf stability and excellent appetizing property. According to various estimates, 
soup market in India was in the range of INR 100-125 crores in 2010 (Juse, 2012). The category of ready to cook soup mixes formed 25 percent of the instant food segments (Juse, 2012). The major brands in ready to cook soup mixes in Indian market are Knorr (Hindustan Uniliver), Maggi (Nestle), Ching's secret (Capital Foods), Bambino (Bambino Agro), Sil (Scandin Food), Campbell's (Weikfield Products) etc.

Instantly cookable dry soup mix was prepared from a mixture of powdered dried stock containing several dried ingredients (Kaisha, 1979; Gokulakrishnan, 2014), in which meat extract was used in dried stock and the process involved was concentration. Harris and Davis (1993) prepared a dry soup mix by mixing dry edible components and the process involved use of hydrolyzed chicken protein and chicken flavourings.

Canned soup prepared from fresh chicken was not in dehydrated form and canning is required for storage and presentation (Deping et al., 2001). Hiroyuki (2002) reported a method for producing the chicken soup stock in which chicken extract was used for making soup and the process involved vacuum condensation. Deboning and mincing the pressure cooked meat during preparation of chicken soup, increases the chance of postcooking microbial contamination and further cooking of meat with bone increased the fat content of the final product (Sachindra et al., 2007).

\section{Snack foods}

Consumers are highly cherished by snacks due to its convenience nature and overwhelming taste and flavor. Due to high nutritive value and superior sensory qualities, a broad range of snacks from plant and animal origins are consumed and sold under various geographical indications. The present global trends and lifestyle factors are currently driving the snack food industry and some of these factors are changing and extended working pattern, increasing number of single person households, different eating times and food choices by individual family members and increasing perception of food as a reward (Gokulakrishnan, 2014).

Snack foods being convenient food items are most suitable for working women, school age children and highly mobile population (Lusas and Rhee, 1987). Snacks have become one of the major groups of the functional food products in diet (Roberts, 2002) which can serve the purpose of healthy food, entertaining and tasty food and ethnic cuisines of consumers (Anon, 1998). Snack food products include extruded snacks, puffed cereals, popcorns, rice flakes, potato chips, french fries and Indian home made products like papads, kurdai, chakali etc. which may be consumed after frying or roasting (Nath et al., 2007). These foods are prepared from natural ingredients to yield products with specified functional properties, have become an integral part of the eating habits of majority of world's population (Reid, 1998). Meat incorporation improves flavour, taste and nutritive value of the products. Several meat based snacks like curls, chips and samosa had been developed by Sharma and Kondaiah (2005). Spent hen meat powder incorporated papad (Gokulakrishnan, 2014) and bhujia (Talukder et al., 2015) were found self stable with high sensory acceptance during ambient storage for 60 days and 45 days respectively.

In conclusion, spent hens are considered as byproduct of egg industry which is rich in fat and cholesterol content, and poor in functional characteristics, juiciness and tenderness. Effective utilization of spent hen meat is one of the urgent requirements of Indian poultry industry. Spent hens are 
usually used in feed production, concentrated stock preparations, or in domestic consumption of soups and stews. Millions of people worldwide especially in under developed and developing countries suffer from serious protein energy malnutrition problem, due to acute shortage of animal protein in the diet. Being a good protein source it can be effectively used for production of different convenient and self stable products. Though some studies were carried out by different researcher for production of comminuted, restructured, dried, canned, soup or snacked products from spent hen meat, but commercially yet to be popular such products. The further technological developments in production and processing of spent hen meat products can fetch extreme popularity in coming future.

\section{References}

Abe, H.A., Kimura, T. and Yamuchi, K. (1996). Effects of collagen on the toughness of meat from spent laying hens. J. Jpn. Soc. Food Sci. Technol., 43(7): 831-834.

Ajuyah, A.O., Hardin, T.R., Cheung, K. and Sim, J.S. (1992). Yield, lipid, cholesterol and fatty acid composition of spent hens fed full-fat oil seeds and fish meal diets. Journal of Food Science, 57(2): 338-341.

Akiba, Y., Toyamizu, M., Takahashi, K. and Sato, K. (2001). Nutrition: the key role for optimization of growth and carcass quality in broiler chickens. Asian-Aust. $J$. Anim. Sci., 14(5): 148-163.

Anna Anandh, M. and Annal Villi, R. (2018). Quality and Acceptability of Restructured Spent Hen Meat Nuggets Prepared from Spent Hen Meat Emulsion and Ground Spent Hen Meat Batter. Int.J.Curr.Microbiol.App.Sci., 7(2): 220225.

Anon, (1998). An interview with McCormik on trends in snack food industry. Cereal Food World, 43: 60-65.

Bailey, A.J. (1984). The chemistry of intramolecular collagen. Recent Advances in
Meat Science. London, The Royal Society of Chemistry. Pp. 22-40.

Baker, R.C., Darfler, J.M. and Vadera, D.V. (1969). Effect of type, age and freezing of poultry meat before processing on quality of chicken frankfurters. Poult. Sci., 49: 747-751.

Barbara, O., Rennars, B.A., Ronald, F., Ertl, B.S., Gail, L., Gossman, B.S., Richard, A., Robbins, M.D., Stephen, I. and Rennard, M.D. (2000). Chicken soup inhibits neutrophil chemotaxis in vitro. Chest, 118: 1150-1157.

Bhoyar, A.M., Pandey, N.K., Anand, S.K. and Verma, S.S. (1997). Effect of incorporating texturized soy protein and milk co precipitates on the quality characteristics of restructured chicken steaks. Indian Journal of Poultry Science, 32(3): 253-258.

Boles, J.A. and Shand, P.J. (1999). Effects of raw binder system, meat cut and prior freezing on restructured beef. Meat Science, 53: 233-239.

Caroline, N.L. and Schwartz, H. (1975). Chicken soup rebound and relapse of pneumonia: report of a case. Chest 67: 215-216.

Chidandandiah and Sanyal, M.K. (2001). Quality of soup prepared from spent hens head and whey. Indian Journal of Poultry Science, 36: 240-42.

Chueachuaychoo, A., Wattanachant, S. and Benjakul, S. (2011). Quality characteristics of raw and cooked spent hen Pectoralis major muscles during chilled storage: Effect of salt and phosphate, International Food research Journal, 18: 601-613.

Deogade, A.H., Zanjad, P.N. and Raziuddin, M. (2008). Value Added Meat Products. Vet. World, 1(3): 88-89.

Deping, C.N.L., Anhui, C.N.Z. and Yuiki, Y. (2001). Canned chicken soup. Patent Number CN 1293013.

Gadekar, Y.P., Kokane, R.D., Suradkar, U.S., Thomas, R., Das, A.K. and Anjaneyulu, A.S.R. (2010). Shelf stable meat pickles A review. Int. Food Res. Journal, 17: 
221-227.

Gokulakrishnan, P. (2014). Development and quality evaluation of spent hen meat powder and its utilization in convenient meat products. Ph.D. Thesis Deemed University, IVRI, Izatnagar.

Haque, A.K., Lyons, J.J. and Vandepopulier, J.J. (1991). Extrusion processing of broiler starter diets containing ground whole hens, poultry by products meal, feather meal (or) ground feathers. Poultry Science, 70: 234-40.

Harris, N.E. and Davis, B.A. (1993). Dry soup mix. US Patent Number 5,232,732.

Hedrick, H.B., Aberie, E.T., Forrest, J.C., Judge, M.D. and Merkel, R.A. (1994). Principles of meat science. 3rd edn. Kendell / Hunt Publ Co, Lowa.

Hedrick, H.B., Aberle, E.D., Forrest, J.C., Judge, M.D. and Merkel, R.A. (1993). Principles of Meat Science. 3rd ed. Iowa, Kendall/Hunt Publ. Co.

Hiroyuki, H. (2002). Chicken soup stock and method for producing the same. Japanese Patent Number JP 2002045154.

Jay, J.M., Loessner, M.J. and Golden, D.A. (2005). Modern Food Microbiology. $7^{\text {th }}$ ed. Springer (India) Private Ltd. Pp. 443 447.

Jayaraman, K.S., Das, H. and Gupta, D.K. (1992). Dehydration of fruits and vegetables - recent developments in principles and techniques, Drying Technol., 10: 1-50.

Juse, S. (2012). Process development for dehydrated flavoured chicken shreds from spent hen meat. M.V.Sc. thesis submitted to the Maharashtra Animal and Fishery Science University, Nagpur, India.

Kaisha, T.S. (1979). Instantly cookable dry soup mix. Patent Number GB 2007489.

Kalikannan, K., Anjaneyulu, A.S.R. and Shanthi, D. (2007). Effect of egg proteins on the quality and refrigerated storage life of chicken patties made with broiler, spent hen meat and by products. International Journal of Food Science and Technology, 42: 579-586.

Kharaisheh, M.A.M., Cooper, T.J.R. and
Magee, T.R.A. (1997). Microwave and air drying: Fundamental considerations and assumptions for the simplified thermal calculations of volumetric power absorption. J. Food Eng., 33: 207-219.

Kim, S.M. and Ahn, D.U. (1997). Effects of Dietary alpha-Linolenic Acid on the Fatty Acid Composition and Storage Stability of Processed Meat Products from Spent Hen. Food Biotechnol., 6: 87-92.

Kondaiah N. (1993). Products from spent hen. Poultry International, 49(1):46-47.

Kondaiah, N. and Panda, B. (1992). Processing and utilization of spent hens. World Poult. Sci., 48: 255-268.

Kondaiah, N., Anjaneyulu, A.S.R., Singh, R.P. and Panda, B. (1990). Incorporation of whole egg liquid and potato in chicken nuggets. Indian Journal of Poultry Science, 25(3): 226-228.

Kumar, S. 2009. Development and quality evaluation of chicken enriched noodles. Thesis, M.V.Sc. Chaudhary Charan Singh Haryana Agricultural University, Hisar, Haryana, India.

Kumar, S., Anjaneyulu, A.S.R. and Gupta, H.K. (2001). Sustained animal production. SSARM. Hisar, CCS Haryana Agricultural University. Pp. 223-232.

Lee, S.O., Min, J.S., Kim, I.S. and Lee, M. (2003). Physical evaluation of popped snacks from spent hen meat. Meat Sci., 64: 383-390.

Leistner, L. and Gorris. L.G.M. (1995). Food preservation by hurdle-technology. Trends Food Sci., 6: 41-46.

Lingaiah and Prabhakara Reddy (2001). Quality of chicken meat patties containing skin and giblets. Journal of Food Science and Technology, 38(4): 400-401.

Lusas, E.W. and Rhee, K.C. (1987). Extrusion processing as applied to the snack foods and breakfast cereals. Ch. 16. In: Dupont, J. and Osman, E.M. ed. Cereals and Legumes in Food Supply. Ames, Iowa State University Press. Pp. 201.

Lyons, J.J. (2001). Spent hen utilization. III Midwest Poultry Federation Egg Production Workshop; St. Paul, Minn. 
Mt. Morris, U.S.A: Watt Publsihing [cited 2005 Mar 18]. Available from: http://www.wattnet.com/library/download 3D7sphened.pdf.

Mackie, I.M. (1994). Fish protein. In: Hudson, B.J.F. ed. New and Developing Sources of Food Proteins. London, Chapman and Hall. Pp. 95.

Mahapatra, C.M. (1992). Poultry Products Technology-Prospectus and Problems. Poult. Guide, 29: 69-70.

Mahapatra, C.M. and Verma, S.S. (1998). Quality of chicken nuggets as affected by addition of different types of meat. Indian Journal of Poultry Science, 33(3): 35936.

Mahapatra, C.M., Pandey, N.K., Goyal, R.C. and Verma, S.S. (1984). Use of different binders on acceptability and composition of chicken patties. Indian J. Poult. Sci., 19(4): 287-289.

Mandigo, R.W. (1986). Restructuring of muscle foods. Food Technology, 40: 85-89.

Mendiratta, S.K., Anjaneyulu, A.S.R., Lakshmanan, V. and Suresh Devatkal. (2004). Comparative efficacy of different tenderizing agents for tenderization of spent hen meat. Indian Journal of Poultry Science, 39(1): 37-42.

Nag, S., Sharma, B.D. and Sushil Kumar. (1998). Quality attributes and shelf life of chicken nuggets extended with rice flour. Indian Journal of Poultry Science, 33(2): 182-186.

Nath, A., Chattopadhyay, P. and Majumdar, G. (2007). High temperature short time air puffed ready-to-eat (RTE) potato snacks: Process parameter optimization. J. Food Eng., 80: 770-780.

Patnaik, G. (1993). Marketing of poultry products. An overview. In : All India Poultry Year Book. Business Directory, 1993- 1994, New Delhi, 24, Pp. 75-81.

Prabhakara Reddy, K. and Srinivasa Rao, T. (1997). Influence of Binders and Refrigerated Storage on the Quality Characteristics of Chicken Patties. Indian Journal of Poultry Science, 41(2): 110114.
Prabhakara Reddy, K. and Vijayalakshmi, K. (1998). Effect of incorporation of skin, gizzard, heart and yolk on the quality of frozen chicken meat sausages. Journal of Food Science and Technology, 35(3): 276-278.

Premavalli, K.S. (2000). Convenience foods for defence forces based on traditional Indian foods. Defence Sci. J., 50(4): 361-369.

Rao, K.H., Anjaneyulu, A.S.R., Singh, R.R.B., Dubey, P.C. and Yadav, P.L. (1997). Quality of nuggets and patties from mutton with incorporation of milk co precipitates. Journal of Food Science and Technology, 34(4): 331-334.

Reid, R. (1998). Hot and fruity: the future for snack flavours. Food Reviews, 25: 15-21.

Rennard, B.O., Ertl, R.F., Gossman, G.L., Robbins, R.A. and Rennard, S.I. (2000). Chicken soup inhibits neutrophil chemotaxis in vitro. Chest, 118: 1150-57.

Rhee, K., Cho, S.H. and Pradahn, A.M. (1999). Composition, storage stability and sensory properties of expanded extrudates from blends of corn starch and goat meat, lamb, mutton, spent fowl meat, or beef. Meat Sci., 52: 135-141.

Roberts, W.A. (2002). A function of health. Prepared Foods. Pp. 27-30.

Rocha Garcia, C.E., Youssef, E.Y., Souza, N.E., Matsushita, M., Figueiredo, E. and Shimokomaki, M. (2003). Preservation of Spent Leghorn Hen Meat by a Drying and Salting Process. J. Appl. Poult. Res., 12: 335-340.

Rongsensusang, Sudhakar Reddy, K., Kondal Reddy, K. and Dhanalakshmi, K. (2005). Effect of starter diets containing ground whole hens, poultry by products meal, feather meal (or) ground feathers. Poultry Science, 70: 234-240.

Sachdev, A.K., Ramgopal and Verma, S.S. (1996). Efficacy of different extenders in chicken meat loaf. Indian Journal of Poultry Science, 31(2): 150-152.

Sachindra, N.M.B., Sakhare, P.Z., Puttarajappa, P. and Rao, D.N. (2007). Chicken soup mix composition and a process for preparing the same. Patent Number US 
7255889 B2.

Saketkhoo, K., Januszkiewics, B.S. and Sackner, M.A. (1978). Effects of drinking hot water, cold water and chicken soup on nasal mucus velocity and nasal airflow resistance. Chest, 74: 408-410.

Seideman, S.C., Durland, P.R., Quenzer, N.M. and Carlson, C.W. (1981). Utilization of spent fowl muscle in the manufacture of restructured steaks. Poultry Science, 61: 1087-1093.

Sekhon, K.S. and Bawa, A.S. (1991). Effect of frozen storage and extenders on the quality of meat tikkas from culled hens and broiler breeder males. Journal of Food Science and Technology, 28(5): 296-300.

Sharma, B.D. and Kondaiah, N. (2005). Development of buffalo meat samosa and evaluation of its storage quality in low vacuum family pack under frozen condition. J. Vet. Pub. Health, 3: 59-62.

Sharma, G.K. and Bawa, A.S. (2003). DFLE in the services of specific consumersconvenience foods and operational rations. IFCON, Dec.5-8.

Shukla, V., Talukder, S., Vishnuraj, M.R. and Sharma, B.D. (2014). Effect of incorporation of carrot and papaya on quality characteristics and shelf life of chicken soup. Indian Journal of Poultry Science, 49(1): 81-85.

Singh, R.R.B., Rao, K.H., Anjaneyulu, A.S.R., Rao, K.V.V.S., Dubey, P.C. and Yadav, P.L. (1997). Effect of caseinates on physico-chemical, textural and sensory properties of chicken nuggets from spent hens. Journal of Food Science and Technology, 34(4): 316-318.

Souza K.M.R. de, Araujo, R.B., Santos, A.L. dos, Rodrigues, C.E.C., Faria, D.E. de and Trindade, M.A. (2011). Adding value to the meat of laying hens manufacturing sausages with a health appeal. Brazilian journal of poult. sci., 13(1): 57-63.

Talukder, S., Mendiratta, S.K., Kumar, R.R., Arvind Shukla, V., Vishnuraj, M.R., and Kandeepan, G. (2015). Development and characterization of shelf-stable spent hen meat bhujia. Indian Journal of Poultry Science, 50(3): 305-309.

Vadivambal, R. and Jayas, D.S. (2007). Changes in quality of microwave-treated agricultural products- A review. Biosystems Eng., 98: 1-16.

Varnam, A.H. and Sutherland, J.P. (1995). Meat and meat products: technology, chemistry and microbiology. London, Chapman and Hall. Pp. 404-405.

Voller-Reasonover, L., Han, I.Y., Acton, J.C., Titus, T.C., Bridges, W.C. and Dawson, P.L. (1997). High temperature processing effects on the properties of fowl meat gels. Poult. Sci., 76: 774-779.

Wenham, L.N., Fairbain, K. and McLeod, W. (1973). Eating quality of mutton compared with lamb and its relationship to freezing practices. J. Anim. Sci., 36: 1081-1087.

\section{How to cite this article:}

Sarkar, B. K., S. Upadhyay, P. Gogoi, S. Choudhury and Deuri, D. 2020. Utilization of Spent Hen in Food Industry- A Review. Int.J.Curr.Microbiol.App.Sci. 9(07): 1442-1451. doi: https://doi.org/10.20546/ijcmas.2020.907.165 